\title{
Prevalence and abundance of Cryptosporidium parvum and Giardia spp. in wild rural rodents from the Mazury Lake District region of Poland
}

\author{
A. BAJER ${ }^{1}$, M. BEDNARSKA ${ }^{1}$, A. PAWEŁCZYK ${ }^{1}$, J. M. BEHNKE ${ }^{2}$, F. S. GILBERT ${ }^{2}$ \\ and $\mathrm{E} . \mathrm{SINSK} \mathrm{I}$ \\ ${ }^{1}$ Department of Parasitology, Institute of Zoology, University of Warszawa, ul. Miecznikowa 1, Warszawa 02-096, \\ Poland \\ ${ }^{2}$ School of Life and Enviromental Sciences, University Park, University of Nottingham, Nottingham NG7 2RD, UK
}

(Received 12 November 2001 ; revised 19 February 2002; accepted 21 February 2002)

\begin{abstract}
SUMMARY
Prevalence and abundance of Cryptosporodium parvum and Giardia spp. were studied in 3 species of rodents from forests and abandoned agricultural fields in N.E. Poland (Clethrionomys glareolus $n=459$; Microtus arvalis $n=274$; Apodemus flavicollis $n=209)$. Overall prevalence was consistently higher in the voles compared with A. flavicollis (70.6, 73.0 and $27 \cdot 8 \%$ respectively for $C$. parvum and $93.9,96 \cdot 3$ and $48 \cdot 3 \%$ respectively for Giardia spp.). Prevalence and abundance of infection also varied markedly across 3 years with 1998 being a year of higher prevalence and abundance with both species. Fewer older animals (especially $C$. glareolus and $M$. arvalis) carried infection with $C$. parvum and infections in these animals were relatively milder. Although seasonal differences were significant, no consistent pattern of changes was apparent. Host sex did not influence prevalence or abundance of infection with C. parvum, but made a small contribution to a 4-way interaction (in 5-way ANOVA) with other factors in the case of Giardia spp. The 2 species co-occurred significantly and in animals carrying both parasites there was a highly significant positive correlation between abundance of infection with each, even with between-year, seasonal, host age, sex and species differences taken into account. Quantitative associations were confined to the 2 vole species in the study. These results are discussed in relation to the importance of wild rodents as reservoir hosts and sources of infection for local human communities.
\end{abstract}

Key words: Clethrionomys glareolus, Apodemus flavicollis, Microtus arvalis, Cryptosporidium parvum, Giardia spp., ecology, interactions, co-occurrence.

\section{INTRODUCTION}

The intestinal protozoan parasite, Cryptosporidium parvum, Tyzzer, 1912, is considered to be an important cause of diarrhoea in humans and in domestic livestock (Griffiths, 1998; de Graaf et al. 1999). A wide range of natural reservoir hosts has been reported for C. parvum (Sturdee, Chalmers \& Bull, 1999) and experimental transmission studies have established that some strains of this organism lack host specificity and can be transmitted between mammalian hosts (O’Donoghue, 1995; Okhuysen et al. 1999). However, the existence of distinct hostspecific genotypes, and the extent of their abilities to infect other hosts, are both subjects of intensive current investigation. The complexity involved is reflected in a recent study, employing molecular techniques, which provided evidence for 2 new genotypes of the parasite, both infective for humans and identical to feline and canine isolates (Pieniazek et al. 1999).

* Corresponding author: School of Biological Sciences, University Park, University of Nottingham, Nottingham, NG7 2RD. Tel: 0115951 3208. Fax: 01159513252. E-mail: jerzy.behnke@nottingham.ac.uk
Giardia spp. are also very common intestinal parasites responsible for acute and chronic infections in humans and other animals (Novotny et al. 1990; Tonks, Brown \& Ionas, 1991). For G. intestinalis ( $G$. duodenalis), the commonest species infecting mammals and the principal cause of human giardiasis, a wide range of animal reservoir hosts, including rodents, is believed to exist (Marino et al. 1992; Karanis et al. $1996 a, b)$.

Environmentally resistant and long-term infective oocysts of $C$. parvum and cysts of $G$. intestinalis are often found in surface water (Wallis et al. 1996; Chalmers et al. $1997 b$ ) and are responsible for waterborne outbreaks of cryptosporidiosis and giardiasis affecting human communities (Majewska \& Kasprzak, 1995 ; Cicirello et al. 1997). However, for the most part, sources of environmental contamination remain unresolved and hence detailed field surveys of potential wildlife reservoirs are required to fully elucidate the diversity of transmission routes to human communities and to domestic livestock. Wild rodents are known to act as reservoir hosts, especially those species with commensal relationships with humans e.g. wild house mice, Mus spp. and rats Rattus spp. (Webster \& MacDonald, 1995; 
Marino et al. 1992; Chilvers et al. 1998; Abd elWahed et al. 1999). Less is known about the transmission potential from wild voles and noncommensal mice, although both groups of rodents often live at high density on the outskirts of human communities and are known to carry both $C$. parvum and Giardia spp. (Sinski, Hlebowicz \& Bednarska, 1993; Bajer, Bednarska \& Sinski, 1997; Sinski, Bednarska \& Bajer, 1998). In N.E. Europe, bank voles Clethrionomys glareolus, yellow-necked mice Apodemus flavicollis, and wood mice A. sylvaticus are the dominant rodents in woodland habitats and common voles Microtus arvalis in the open grasslands. Earlier studies on forest rodents in Central Europe (Karanis et al. 1996a) suggested that these animals also could be an important source of Giardia spp. cysts for human communities and data on the distribution of $C$. parvum in rodents in agricultural sites in the United Kingdom (Chalmers et al. 1995, $1997 a$; Webster \& MacDonald, 1995) support the idea that rodents also act as reservoir hosts further afield.

However, there is still a paucity of information on variation in patterns of infection throughout seasons and across years in rural wild rodents, and on the relative importance of hosts of different species, sex and age as reservoirs of infection. In this paper we report on the prevalence and abundance of these 2 intestinal parasites in 3 populations of small rodents inhabiting 2 neighbouring habitats in the Mazury Lake District region in north-eastern Poland. We test the hypothesis that prevalence and abundance of infection differ between species of rodents in this region and we evaluate the extent of annual and seasonal variation, as well as the influence of the intrinsic factors, host age and sex.

\section{MATERIALS AND METHODS}

\section{Study sites}

Our study site was located east of the nature reserve surrounding Lake Luknajno, and north of Lake Śniardwy, near the town of Mikolajki in the Mazury Lake District region of N.E. Poland. Trapping was conducted in mature woodland with Scots pine (Bajer et al. 2001) and in fields used for growing cereals until 1991 and essentially lying fallow since then.

\section{Trapping and sampling wild rodents}

Rodents were caught live in locally constructed wooden traps and processed according to the procedures described in detail by Bajer et al. (2001). Visits to the study sites comprised at least a 4-day duration, at approximately 4-week intervals from late March until mid-November over a 3 year period (19971999). For both practical and animal welfare reasons, it was not possible to visit the sites in the period between November and March because the ground was mostly hard frozen and deep snow covered our sites for most of the winter period. The months between March and November were divided into 3 seasons, comprising spring (March to early June), summer (late June to August) and autumn (September to November).

At the field station in Urwitalt, all animals were inspected, identified, sexed, relevant morphometric data were recorded and they were weighed (to the nearest $0.5 \mathrm{~g}$ ). After the inspection most animals were marked by standard toe clipping (Fullagar \& Jewell, 1965) and released as near as possible to the original site of capture, whilst others (approximately $35 \%$ ) were killed for recovery of endoparasites (data to be published elsewhere).

\section{Ageing rodents}

Three age classes were established on the basis of weight (Morris, 1972) and sexual development, corresponding to immature juveniles (age class 1), young mature animals (age class 2) and adults (age class 3). For C. glareolus age classes 1,2 and 3 comprised respectively voles $<15 \mathrm{~g}$ in weight (approximately less than 1.5 month old), $15-19.5 \mathrm{~g}$ in weight ( 1.5 to 2.5 months old) and $>19.5 \mathrm{~g}(2.5$ months and older; Mazurkiewicz, 1972; Kozakiewicz, 1976). For $M$. arvalis these were respectively voles $<14 \mathrm{~g}$ (less than 1.5 month old), 14.5-19 g (1.5 to 2.5 month old $)$ and $>19 \mathrm{~g}(2.5$ months and older; Adamczewska-Andrzejewska, 1973). For A. flavicollis the 3 age classes corresponded to mice $<20 \mathrm{~g}$ (less than 3.5 month old), $20-30 \mathrm{~g}$ (3.5 to 7 month old) and $>30 \mathrm{~g}$ (7 months and older; Swierczewska, 1981), respectively.

\section{Faecal analysis}

Individual faecal samples were collected from traps immediately after retrieval of the captured rodent. A few pellets were used to prepare thin faecal smears which were stained according to modified ZiehlNeelsen technique (Henriksen \& Pohlenz, 1981), after drying and fixation in methanol. Then, at least 200 fields of vision under $400 \times$ magnification were carefully examined on each slide for presence or absence of $C$. parvum oocysts. These were identified on the basis of their characteristic size $(4-5 \times 3 \cdot 5-4.5$ $\mu \mathrm{m})$, general morphology and bright red/pink colour. For some animals only this method provided evidence of infection and in such cases we recorded a minimum detectable intensity, entered into the quantitative analysis as 400 oocysts/ml of concentrated sample (see below).

For identification of genus and quantification of infection we used a commercially available immunofluorescence assay (IFA) capable of labelling oocysts and cysts of the protozoa (MerIFluor Cryptospori- 
Table 1. The structure of the sampled rodents by host species, year of capture, host sex and age

\begin{tabular}{|c|c|c|c|c|c|c|}
\hline \multirow[b]{2}{*}{ Year } & \multirow[b]{2}{*}{ Sex } & \multicolumn{3}{|l|}{ Age } & \multicolumn{2}{|c|}{ Totals by } \\
\hline & & 1 & 2 & 3 & Sex & Year \\
\hline \multicolumn{7}{|c|}{ Clethrionomys glareolus } \\
\hline \multirow[t]{3}{*}{1997} & Male & 44 & 43 & 9 & 96 & \\
\hline & Female & 29 & 29 & 18 & 76 & \\
\hline & Combined & 73 & 72 & 27 & & 172 \\
\hline \multirow[t]{3}{*}{1998} & Male & 22 & 27 & 25 & 74 & \\
\hline & Female & 27 & 10 & 24 & 61 & \\
\hline & Combined & 49 & 37 & 49 & & 135 \\
\hline \multirow[t]{3}{*}{1999} & Male & 27 & 30 & 15 & 72 & \\
\hline & Female & 33 & 25 & 22 & 80 & \\
\hline & Combined & 60 & 55 & 37 & & 152 \\
\hline \multicolumn{2}{|c|}{ Total by age } & 182 & 164 & 113 & Ove & 1 total 459 \\
\hline \multicolumn{7}{|c|}{ Apodemus flavicollis } \\
\hline \multirow[t]{3}{*}{1997} & Male & 12 & 15 & 27 & 54 & \\
\hline & Female & 5 & 26 & 24 & 55 & \\
\hline & Combined & 17 & 41 & 51 & & 109 \\
\hline \multirow[t]{3}{*}{1998} & Male & 1 & 4 & 5 & 10 & \\
\hline & Female & 0 & 3 & 3 & 6 & \\
\hline & Combined & 1 & 7 & 8 & & 16 \\
\hline \multirow[t]{3}{*}{1999} & Male & 3 & 15 & 25 & 43 & \\
\hline & Female & 7 & 15 & 19 & 41 & \\
\hline & Combined & 10 & 30 & 44 & & 84 \\
\hline \multicolumn{2}{|c|}{ Total by age } & 28 & 78 & 103 & Ove & 1 total 209 \\
\hline \multicolumn{7}{|c|}{ Microtus arvalis } \\
\hline \multirow[t]{3}{*}{1997} & Male & 10 & 11 & 14 & 35 & \\
\hline & Female & 14 & 5 & 14 & 33 & \\
\hline & Combined & 24 & 16 & 28 & & 68 \\
\hline \multirow[t]{3}{*}{1998} & Male & 9 & 8 & 12 & 29 & \\
\hline & Female & 10 & 9 & 20 & 39 & \\
\hline & Combined & 19 & 17 & 32 & & 68 \\
\hline \multirow[t]{3}{*}{1999} & Male & 17 & 14 & 43 & 74 & \\
\hline & Female & 12 & 21 & 31 & 64 & \\
\hline & Combined & 29 & 35 & 74 & & 138 \\
\hline \multicolumn{2}{|c|}{ Total by age } & 72 & 68 & 134 & \multicolumn{2}{|c|}{ Overall total 274} \\
\hline
\end{tabular}

dium/Giardia (Meridian Diagnostics Inc., Cincinnati, Ohio, USA). For IFA 1 faecal sample (weighing between 0.3 and $1 \mathrm{~g}$ ) from each animal was concentrated using a modified Sheather's sucrose flotation method (Garcia \& Bruckner, 1988). The volume of concentrated material was estimated by comparison to calibrated Eppendorfs and the pellet was resuspended (1:3, v/v, pellet: $10 \%$ formalin; dilution factor $=4)$. Ten $\mu \mathrm{l}$ of suspension were used for the IFA test, which was carried out according to the manufacturer's instructions. Identification was aided by comparison with positive control samples provided in the kit. Wells were examined under $400 \times$ magnification, and the numbers of $C$. parvum oocysts and Giardia spp. cysts were recorded. For estimation of abundance of infection the total numbers of oocysts/cysts detected were multipled by 400 (dilution factor $\times 100=$ oocysts/cysts per $\mathrm{ml}$ ) to give the number $/ \mathrm{ml}$ of concentrated sediment. Thus the lowest limit of detection was 400 oocysts/ cysts $/ \mathrm{ml}$ of concentrated sediment.

\section{Statistical analysis}

Prevalence (percentage of animals infected) was analysed by maximum likelihood techniques based on $\log$ linear analysis of contingency tables, implemented by the software package, Statgraphics Version 7. For each parasite species in turn we entered prevalence of infection as a binary factor (infected $=1$, not infected $=0$ ) and then host species ( 3 levels, C. glareolus, A. flavicollis and $M$. arvalis), year (3 levels, 1997, 1998 and 1999), season (3 levels, spring, summer and autumn), host age (3 levels) and host sex (2 levels) as factors. Beginning with the most complex model, involving all possible main effects and interactions, those combinations not contributing significantly to explaining variation in the data were eliminated stepwise, beginning with the highest-level interaction. A minimum sufficient model was then obtained, for which the likelihood ratio of $\chi^{2}$ was not significant, indicating that the model was sufficient in explaining the data. The interaction 
Table 2. Changes in rodent population density in the study site during 1997-1999

\begin{tabular}{|c|c|c|c|}
\hline \multirow[b]{2}{*}{ Month } & \multicolumn{3}{|c|}{ Relative population density* } \\
\hline & 1997 & 1998 & 1999 \\
\hline \multicolumn{4}{|c|}{ Clethrionomys glareolus } \\
\hline March & $15 \cdot 6$ & N.D. & N.D. \\
\hline April & $8 \cdot 3$ & $10 \cdot 2$ & $7 \cdot 6$ \\
\hline May & $4 \cdot 0$ & $1 \cdot 1$ & $4 \cdot 1$ \\
\hline June & $7 \cdot 2$ & $14 \cdot 4$ & N.D. \\
\hline July & $18 \cdot 0$ & $13 \cdot 4$ & $52 \cdot 3$ \\
\hline August & $31 \cdot 5$ & $34 \cdot 1$ & $85 \cdot 0$ \\
\hline September & $34 \cdot 5$ & $44 \cdot 5$ & $188 \cdot 3$ \\
\hline October & $20 \cdot 0$ & $33 \cdot 5$ & N.D. \\
\hline November & $35 \cdot 4$ & N.D. & N.D. \\
\hline \multicolumn{4}{|c|}{ Apodemus flavicollis } \\
\hline March & $2 \cdot 1$ & N.D. & N.D. \\
\hline April & $3 \cdot 8$ & $1 \cdot 6$ & $3 \cdot 8$ \\
\hline May & $9 \cdot 1$ & $1 \cdot 1$ & $1 \cdot 4$ \\
\hline June & $13 \cdot 6$ & $0 \cdot 7$ & N.D. \\
\hline July & $6 \cdot 7$ & $1 \cdot 7$ & $9 \cdot 3$ \\
\hline August & $16 \cdot 6$ & $3 \cdot 6$ & $13 \cdot 3$ \\
\hline September & $20 \cdot 8$ & $5 \cdot 9$ & $78 \cdot 5$ \\
\hline October & $11 \cdot 4$ & 0 & N.D. \\
\hline November & $20 \cdot 3$ & N.D. & N.D. \\
\hline \multicolumn{4}{|c|}{ Microtus arvalis } \\
\hline March & $2 \cdot 4$ & N.D. & N.D. \\
\hline April & $0 \cdot 6$ & $1 \cdot 6$ & $2 \cdot 5$ \\
\hline May & $0 \cdot 5$ & $1 \cdot 1$ & $7 \cdot 4$ \\
\hline June & $6 \cdot 4$ & 0 & N.D. \\
\hline July & $10 \cdot 0$ & $22 \cdot 6$ & $19 \cdot 4$ \\
\hline August & $14 \cdot 8$ & $5 \cdot 4$ & $30 \cdot 1$ \\
\hline September & $10 \cdot 4$ & $22 \cdot 6$ & N.D. \\
\hline October & $12 \cdot 0$ & $13 \cdot 1$ & N.D. \\
\hline November & $12 \cdot 4$ & N.D. & N.D. \\
\hline
\end{tabular}

* Population density was calculated as the number of rodents trapped divided by trap hours $\times$ trap number $\times$ $10^{-4}$.

N.D., Not done. terms that did not include the infection term reflect differences in numbers of animals sampled in particular categories between years, seasons, species, age and sex categories.

Quantitative data reflecting parasite abundance within hosts were expressed as geometric means (GM) because the data were highly overdispersed (Elliott, 1977; Dash, Hall \& Barger, 1988). These means reflect the abundance of infection as defined by Margolis et al. (1982) and include all subjects within the specified group, infected and not infected, for which relevant data were available. The degree of aggregation in quantitative data was calculated by the Index of Dispersion ( $I=$ the variance to mean ratio) and the Index of Discrepancy $(D)$ as described by Poulin (1993; a value of 0 indicates an even distribution of counts across all hosts and a value of 1 indicates all parasites aggregated in a single host). Frequency distributions of individual species were also tested for goodness of fit to negative binomial, positive binomial and Poisson models by $\chi^{2}$ as described by Elliott (1977) and the negative binomial exponent $k$ is given as appropriate.

Parasite abundance was analysed by GLIM (a statistical system for generalized linear interactive modeling; GLIM 4, PC version, Royal Statistical Society, 1993) as described previously, using models with normal errors after normalization of the data by $\log _{10}(x+1)$ transformation (Crawley, 1993; Wilson \& Grenfell, 1997; Behnke et al. 1999). Year, season, host species, age and host sex (see above for levels) were entered as factors. For models with normal errors the change in deviance is used to calculate the variance ratio, $F$. Significant main effects and interactions from minimum sufficient models are given in the legends to the figures. The residuals from all models were checked for approximately normal distribution.

Quantitative associations between parasites were

Table 3. Summary statistics for prevalence and abundance of infection with Cryptosporidium parvum and Giardia spp. in three rodent host species

\begin{tabular}{|c|c|c|c|c|c|c|c|c|c|}
\hline \multirow[b]{3}{*}{ Host } & \multirow[b]{3}{*}{ Sex } & \multicolumn{4}{|c|}{ Cryptosporidium parvum } & \multicolumn{4}{|c|}{ Giardia spp. } \\
\hline & & \multirow[b]{2}{*}{ Prevalence } & \multirow[b]{2}{*}{$n$} & \multicolumn{2}{|l|}{ Abundance } & \multirow[b]{2}{*}{ Prevalence } & \multirow[b]{2}{*}{$n$} & \multicolumn{2}{|l|}{ Abundance } \\
\hline & & & & $\begin{array}{l}\text { Geometric } \\
\text { mean } \pm\end{array}$ & $95 \% \mathrm{CL}$ & & & $\begin{array}{l}\text { Geometric } \\
\text { mean } \pm\end{array}$ & $95 \% \mathrm{CL}$ \\
\hline \multirow{3}{*}{$\begin{array}{l}\text { Clethrionomys } \\
\text { glareolus }\end{array}$} & Males & $69 \cdot 8$ & 242 & $275 \cdot 6$ & $165 \cdot 4-458 \cdot 9$ & $92 \cdot 3$ & 233 & $17837 \cdot 9$ & $11350 \cdot 7-28032 \cdot 5$ \\
\hline & Females & $71 \cdot 4$ & 217 & $281 \cdot 4$ & $166 \cdot 4-475 \cdot 6$ & $95 \cdot 8$ & 212 & $32238 \cdot 5$ & $21361 \cdot 2-48654 \cdot 4$ \\
\hline & Combined & $70 \cdot 6$ & 459 & $278 \cdot 3$ & $193 \cdot 2-400 \cdot 7$ & 93.9 & 445 & $23648 \cdot 1$ & $17389 \cdot 4-32159 \cdot 2$ \\
\hline \multirow{3}{*}{$\begin{array}{l}\text { Apodemus } \\
\text { flavicollis }\end{array}$} & Males & $29 \cdot 0$ & 107 & $6 \cdot 6$ & $3 \cdot 1-13 \cdot 4$ & $47 \cdot 1$ & 104 & $35 \cdot 8$ & $16 \cdot 0-78 \cdot 5$ \\
\hline & Females & $26 \cdot 5$ & 102 & $5 \cdot 4$ & $2 \cdot 4-11 \cdot 0$ & $49 \cdot 5$ & 99 & $40 \cdot 5$ & $17 \cdot 9-89 \cdot 9$ \\
\hline & Combined & $27 \cdot 8$ & 209 & $6 \cdot 0$ & $3 \cdot 5-9 \cdot 9$ & $48 \cdot 3$ & 203 & $38 \cdot 0$ & $21 \cdot 6-66 \cdot 3$ \\
\hline \multirow{3}{*}{$\begin{array}{l}\text { Microtus } \\
\text { arvalis }\end{array}$} & Males & $71 \cdot 0$ & 138 & $239 \cdot 8$ & $127 \cdot 1-451 \cdot 9$ & $94 \cdot 8$ & 134 & $54352 \cdot 3$ & $31212 \cdot 1-94647 \cdot 8$ \\
\hline & Females & $75 \cdot 0$ & 136 & $373 \cdot 3$ & $197 \cdot 3-705 \cdot 6$ & $97 \cdot 7$ & 133 & $42270 \cdot 9$ & $27420 \cdot 7-65163 \cdot 3$ \\
\hline & Combined & $73 \cdot 0$ & 274 & $298 \cdot 8$ & $190 \cdot 9-467 \cdot 2$ & $96 \cdot 3$ & 267 & $47955 \cdot 0$ & $33788 \cdot 1-68061 \cdot 7$ \\
\hline
\end{tabular}




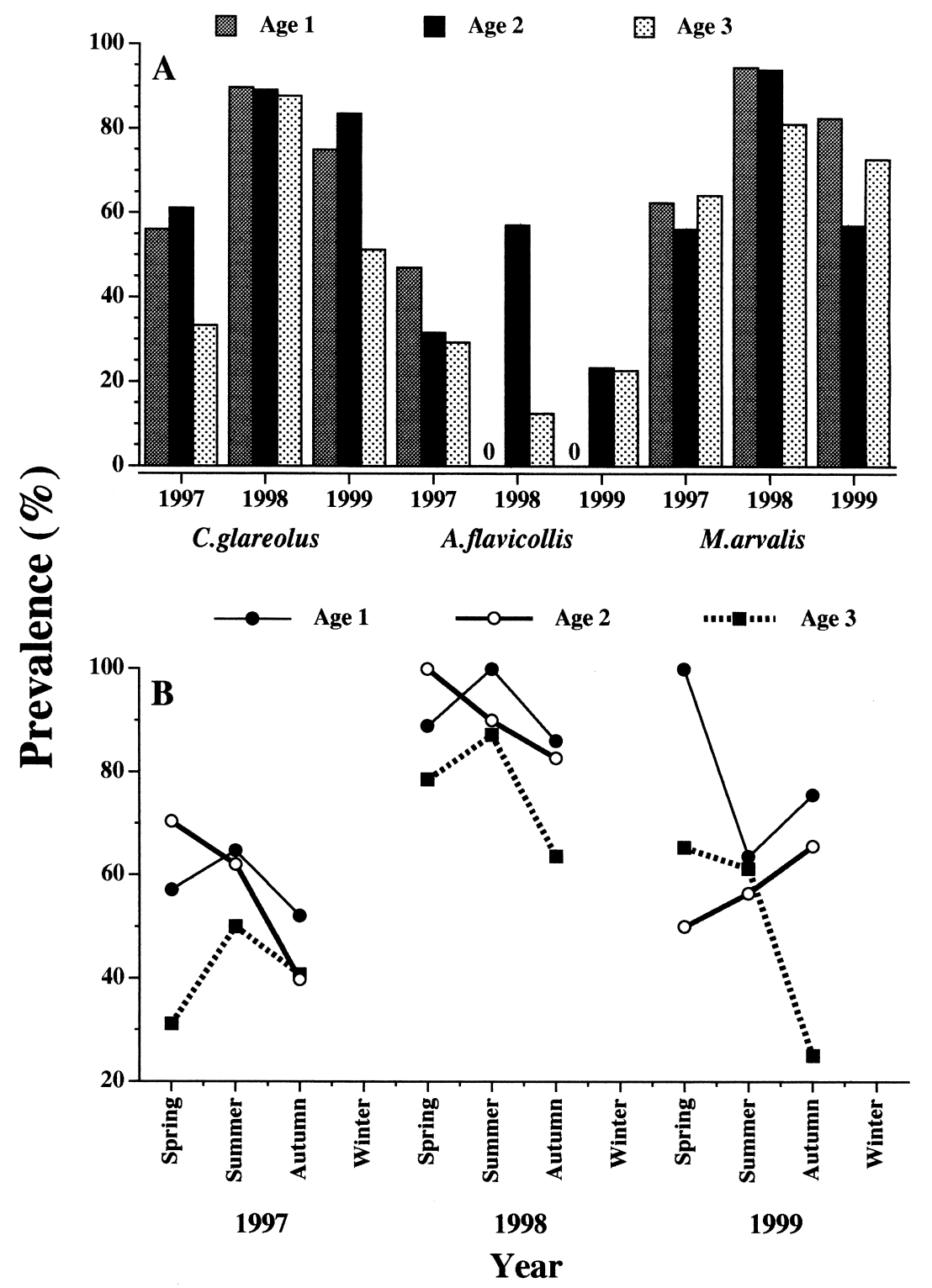

Fig. 1. Prevalence of Cryptosporidium parvum in Clethrionomys glareolus, Apodemus flavicollis and Microtus arvalis. (A) Annual changes in relation to age classes among the 3 host species (year $\times$ species $\times$ age $\times$ infection $\chi_{8}^{2}=20 \cdot 43$, $P=0 \cdot 009$ ). (B) Annual and seasonal variation among age classes with hosts combined (year $\times$ season $\times$ age $\times$ infection $\left.\chi_{8}^{2}=20 \cdot 90, P=0 \cdot 007\right)$. Additional significant terms in the minimum sufficient model included four 3 -way interactions; species $\times$ sex $\times$ age $\left.\chi_{4}^{2}=11 \cdot 8, P=0 \cdot 02\right)$, season $\times \operatorname{sex} \times$ age $\left(\chi_{4}^{2}=10 \cdot 85, P=0 \cdot 03\right)$, season $\times$ species $\times$ age $\left(\chi_{8}^{2}=17 \cdot 1\right.$, $P=0.03)$ and year $\times$ season $\times$ species $\left(\chi_{8}^{2}=136 \cdot 1, P<0 \cdot 0001\right)$, but none of these incorporated infection. Test of the goodness of fit of the minimum sufficient model gave $\left.\chi_{197}^{2}=167 \cdot 4, P=0 \cdot 94\right)$. See text for full explanation.

examined by correlation analysis (Spearman Rankorder correlation test) of raw parasite data from animals carrying both species. We also examined the correlations between the residuals from minimum sufficient 5-way ANOVAs, in order to control for established differences between the host species, years, seasons, host age and sex.

RESULTS

\section{Rodents sampled}

A total of 942 rodents were sampled in the 3 year period and of these $459(48.7 \%)$ were C. glareolus,
$209(22 \cdot 2 \%)$ were A. flavicollis and $274(29 \cdot 1 \%)$ were $M$. arvalis. The structure of the sampled host population by year, host species, sex and age is summarized in Table 1 . Host density was estimated to enable comparison of each of the host populations between the 3 years of the study and this was calculated as the number of trapped animals divided by the product of the number of traps set and the duration of trapping hours (Table 2).

\section{Overall summary statistics}

Table 3 summarizes the overall prevalence rates across the 3 years of the study by host species and by 

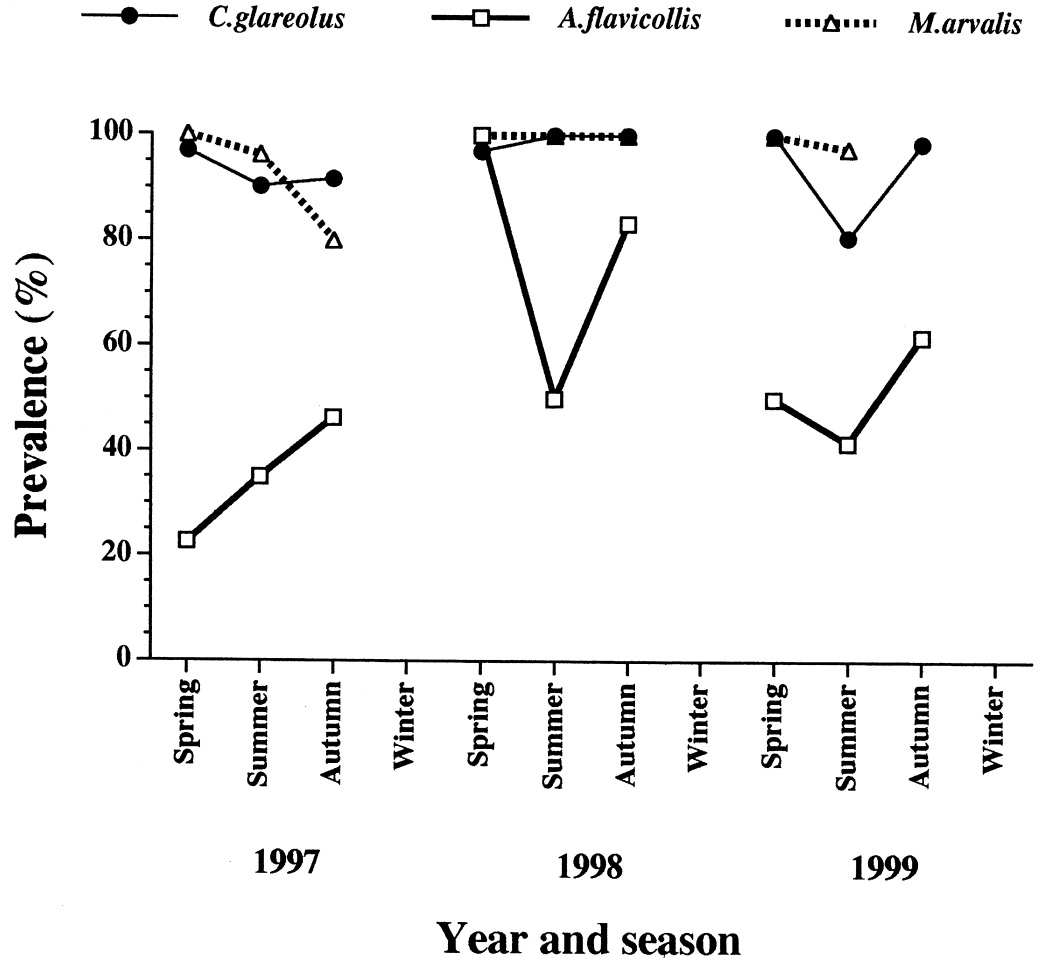

Fig. 2. Annual and seasonal variation in the prevalence of Giardia spp. among Clethrionomys glareolus, Apodemus flavicollis and Microtus arvalis. The minimum sufficient model incorporated 6 interactions, 2 of which included infection (season $\times$ species $\times$ infection, $\chi_{4}^{2}=18 \cdot 9, P=0.0008$ and year $\times$ infection, $\left.\chi_{2}^{2}=29 \cdot 5, P<0 \cdot 0001\right)$ and 4 did not $\left(\right.$ year $\times$ season $\times$ species $\times$ sex, $\chi_{8}^{2}=16 \cdot 8, P=0 \cdot 03$; year $\times$ season $\times$ sex $\times$ age, $\chi_{8}^{2}=15 \cdot 3, P=0 \cdot 05$; year $\times$ species $\times$ sex $\times$ age, $\chi_{8}^{2}=23 \cdot 6, P=0 \cdot 003$; season $\times$ species $\times$ sex $\times$ age, $\chi_{8}^{2}=16 \cdot 1, P=0 \cdot 04$. Test of the goodness of fit of the minimum sufficient model gave $\chi_{183}^{2}=107 \cdot 1, P=1 \cdot 0$. See text for full explanation.

host sex. C. parvum showed a slightly higher prevalence and overall abundance in $M$. arvalis compared with $C$. glareolus, but both parameters were considerably lower in $A$. flavicollis. Much the same picture emerged for Giardia spp. except that prevalence was relatively higher across all species and abundance more intense. The data suggest that A. flavicollis was the least important reservoir host for both species of intestinal protozoa. However, in addition to variation arising from between host differences and from sexes, we sampled animals across 3 seasons and 3 years and samples comprised animals of different age. The analysis that follows quantifies the relative contribution of each factor and their interactions to variation in our data-set.

\section{Prevalence}

For $C$. parvum prevalence varied between the 3 host species and, as can be seen from Fig. 1A, $A$. flavicollis showed lower prevalence compared to the 2 vole species throughout. However, this difference between the species was confounded by some differences between years and among age classes (the year $\times$ species $\times$ age $\times$ infection interaction). Maximum prevalence was observed in 1998 in both $C$. glareolus and in $M$. arvalis and there was even a peak among $A$. flavicollis in age class 2 mice in that year.
The age effect is primarily attributable to the lower prevalence in age class 3 animals in 5 of the 9 sets of age blocks illustrated in Fig. 1A, as well as some of the fluctuations among the remaining classes.

The overall effect of year on prevalence of $C$. parvum can also be seen in Fig. $1 \mathrm{~B}$ in which the species have been combined to illustrate the second interaction (year $\times$ season $\times$ age $\times$ infection). Here again the age effect is clearly apparent, with age class 3 generally showing lower prevalence, and overall little difference between age classes 1 and 2 except in the spring of 1999 (when prevalence for age class $1=100 \%$ and $2=50 \%$ ). Otherwise the seasonal effect showed no consistent pattern (4 peaks in the summer, 4 in the spring and 1 in the autumn) and with the exception of spring 1997 and 1999 and the autumn of 1999, prevalence among age cohorts 1 and 2 was similar across seasons within years.

The prevalence of Giardia spp. also differed markedly between the species (Fig. 2), with $A$. flavicollis showing considerably lower prevalence than the voles, at all times except in the spring of 1998. However, prevalence also varied significantly with season (the season $\times$ species $\times$ infection interaction) and independently with year (the year $\times$ infection interaction). Among voles prevalence remained high throughout (Table 3), not dropping below $80 \%$ in any season (Fig. 2) although there were minor 
Table 4. Measures of aggregation for Cryptosporidium parvum and for Giardia spp. in the combined samples of the three host species

\begin{tabular}{llllll}
\hline \hline Species & $k^{*}$ & $+/-$ & s.E.M $\dagger$ & $I \ddagger$ & $D \S$ \\
\hline Cryptosporidium parvum & 0.202 & $+/-$ & 0.010 & 424491.9 & 0.833 \\
Giardia spp. & 0.495 & $+/-$ & 0.023 & 911573.5 & 0.605 \\
\hline \hline
\end{tabular}

\footnotetext{
* Negative binomial exponent.

+ Standard error of the mean.

$\mp$ Index of dispersion $=$ variance to mean ratio.

$\S$ Index of discrepancy (Poulin, 1993).
}

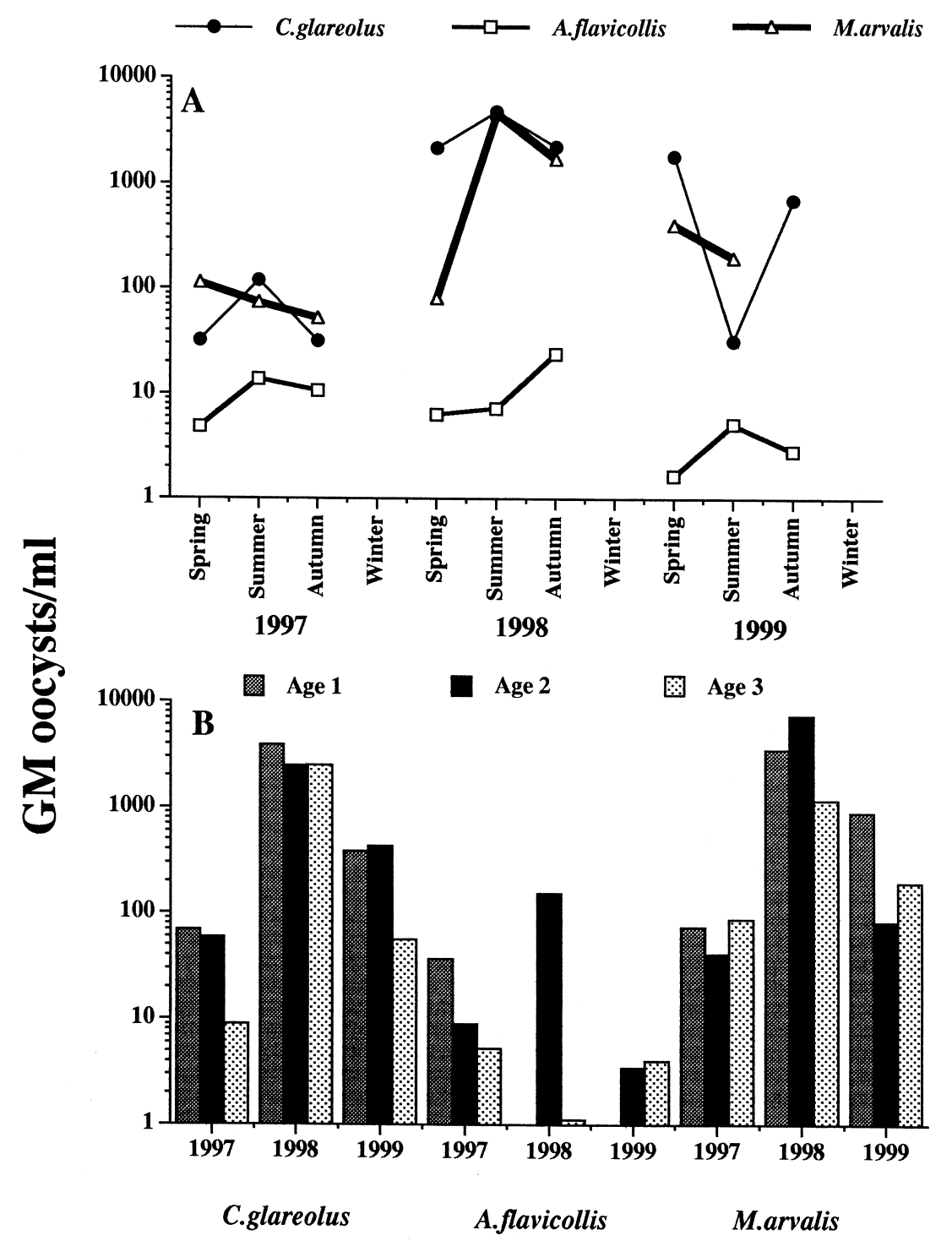

Fig. 3. Variation in the abundance of Cryptosporidium parvum in Clethrionomys glareolus, Apodemus flavicollis and Microtus arvalis (GM = geometric mean). (A) Annual and seasonal variation among the 3 host species. (B) Annual changes in relation to age classes among the 3 host species. The minimum sufficient statistical model incorporated 3 main effects (age $F_{2,934}=6 \cdot 2, P<0 \cdot 005$, species $F_{2,934}=40 \cdot 6, P<0 \cdot 001$ and year $F_{2,934}=56 \cdot 1, P<0 \cdot 001$ ), two 2-way interactions (year $\times$ species $F_{4,904}=8 \cdot 8, P<0 \cdot 001$; year $\times$ season $F_{4,904}=6 \cdot 4, P<0 \cdot 001$ ) and two 3 -way interactions (year $\times$ species $\times$ age $F_{8,853}=2 \cdot 3, P<0 \cdot 025$; year $\times$ season $\times$ species $F_{7,852}=2 \cdot 5, P<0 \cdot 025$ ).

seasonal fluctuations as for example in the autumn of 1997 when prevalence dropped in both vole species compared to spring. However, the major contribution to seasonal and year effects was derived from
A. flavicollis in which prevalence rose from summer to autumn in all 3 years and in which there was considerable variation among spring animals (varying from $22.5 \%$ in 1997 to $100 \%$ in 1998).

\section{CAMBridge JDURNALS}




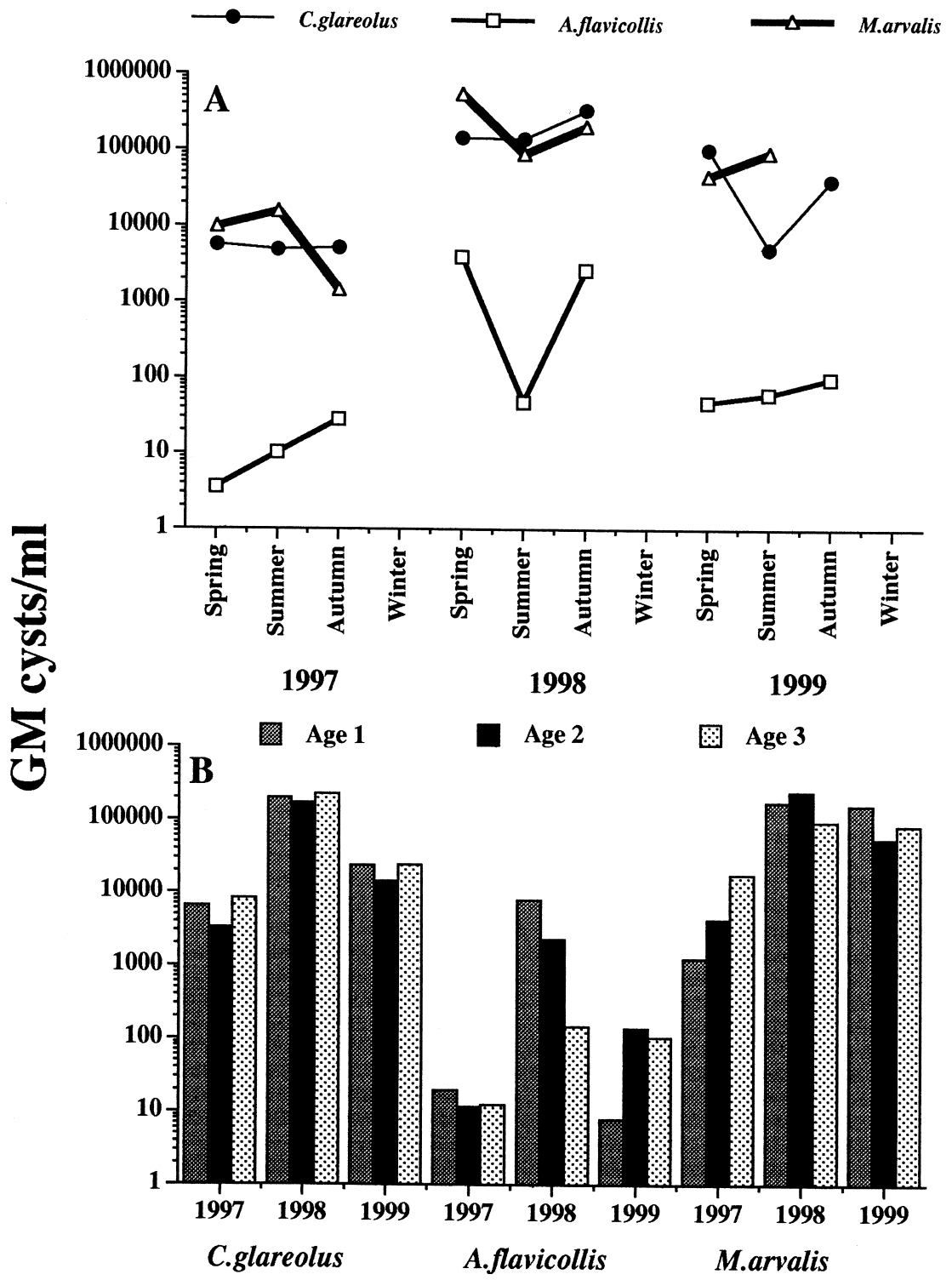

Fig. 4. Variation in the abundance of Giardia spp. in Clethrionomys glareolus, Apodemus flavicollis and Microtus arvalis $(\mathrm{GM}=$ geometric mean). (A) Annual and seasonal variation among the 3 host species. (B) Annual changes in relation to age classes among the 3 host species. The minimum sufficient statistical model incorporated 2 main effects (species $F_{2.907}=169 \cdot 5, P<0 \cdot 001$ and year $F_{2,907}=69 \cdot 9, P<0 \cdot 001$ ), one 2 -way interaction (season $\times$ species $F_{4.877}=3 \cdot 2$, $P<0 \cdot 025)$ and one 4-way interaction (year $\times$ species $\times$ age $\times \operatorname{sex} F_{7,790}=2 \cdot 1, P<0 \cdot 05$ ).

\section{Abundance of infection}

Both species were aggregated in the 3 host populations as shown in Table 4.

There was a considerable difference in the abundance of C. parvum between the host species (Fig. 3). On the whole, the geometric means were an order of magnitude higher in voles, sometimes 2-3 orders higher (Table 3; Fig. 3A, spring 1999), compared with $A$. flavicollis. Quite clearly A. flavicollis harboured much milder infections than the 2 voles. However, there was also a strong influence of year, season and age and these relationships are shown in Fig. 3A and B. As with prevalence the year effect arose because in 1998 infections were markedly more intense than in either 1997 or 1999, particularly among the voles. Seasonal variation was also ap- parent but did not follow a consistent pattern, peaking in all 3 seasons ( 5 of 9 peaks in summer and 2 in the spring) depending on host and year combination (Fig. 3A). The age effect arose from the generally milder infections among the oldest animals (Fig. 3B), notably among C. glareolus, but also in 1998 among $M$. arvalis and in 1997 among $A$. flavicollis.

Variation in the abundance of Giardia spp. is illustrated in Fig. 4, where it can be seen that the principal sources of variation were host species and year of study. These 2 main effects had the major influence on our data, and there were only relatively small contributions from the 2 significant interactions (see legend to Fig. 4). A. flavicollis carried much milder infections than the 2 voles throughout the study. As with C. parvum, 1998 was a year in 

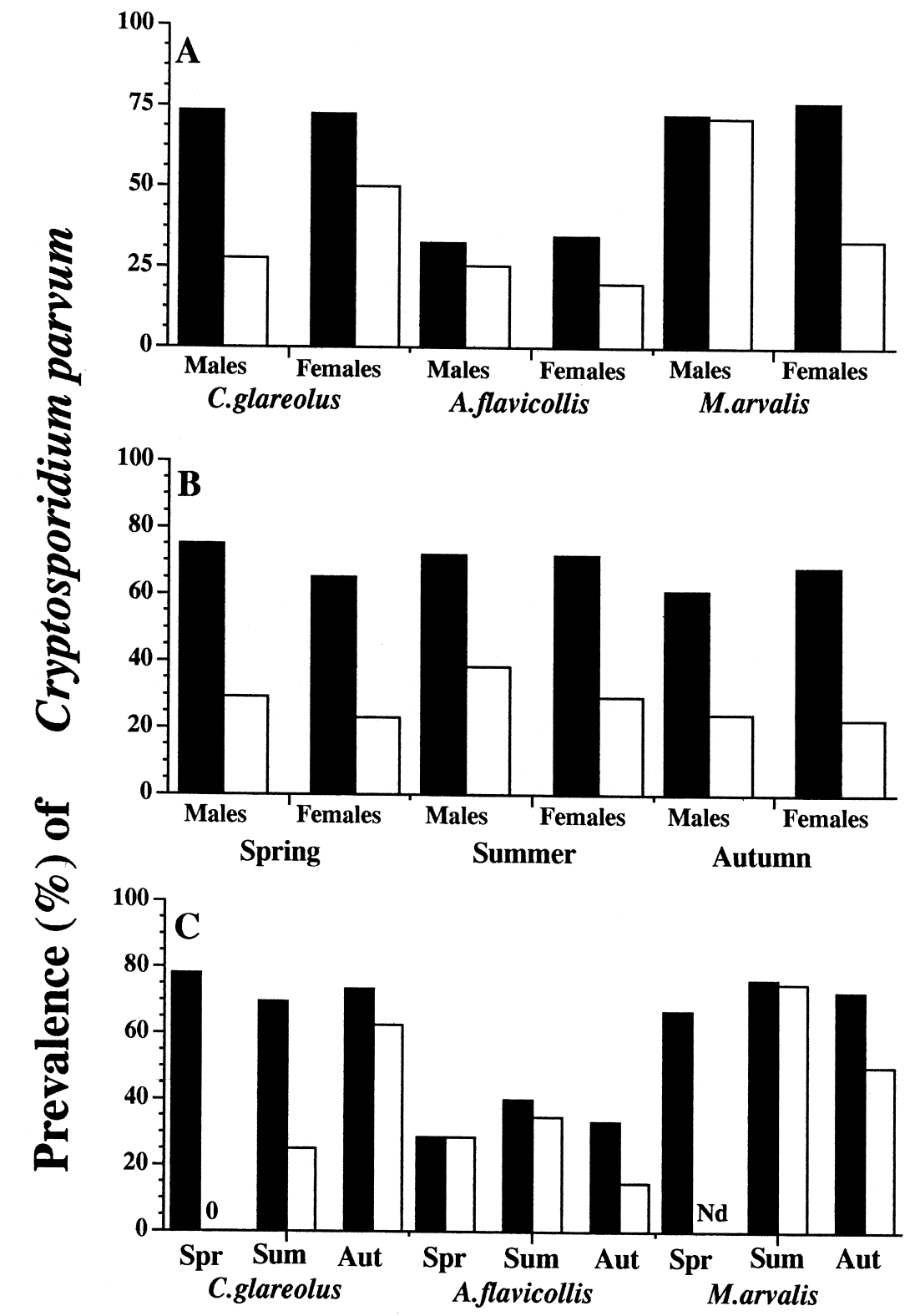

Fig. 5. Co-occurrence of infections with Giardia spp. and Cryptosporidium parvum. The figures show the percentage of animals infected with C. parvum among subsets of animals either carrying ( $\square$ ) or not infected ( $\square$ ) with Giardia spp. (A) Co-occurrence in relation to host species and sex (species $\times \operatorname{sex} \times$ C. parvum $\times$ Giardia spp., $\chi_{2}^{2}=11 \cdot 5$, $P=0.003)$. (B) Co-occurrence in relation to season and host sex (season $\times \operatorname{sex} \times$ C. parvum $\times$ Giardia spp., $\chi_{2}^{2}=9 \cdot 8$, $P=0.008$ ). (C) Co-occurrence in relation to host species and season (season $\times$ species $\times$ C. parvum $\times$ Giardia spp., $\left.\chi_{4}^{2}=17 \cdot 1, P=0 \cdot 002\right)$. Eight additional interactions comprising the minimum sufficient model included various combinations of extrinsic and intrinsic factors and in 5 cases one of the species (not shown). Test of the goodness of fit of the minimum sufficient model gave $\left.\chi_{400}^{2}=161 \cdot 95, P=1 \cdot 0\right)$. See text for full explanation. ( $\mathrm{Spr}=\mathrm{spring}$, Sum $=$ summer, Aut $=$ autumn).

which infections were more intense than in other years, and even among $A$. flavicollis infections were heavier than in the preceding year, but there was essentially no difference between $C$. glareolus and $M$. arvalis. No overall consistent pattern of seasonal changes was evident, with peaks occurring in all seasons ( 4 of 9 peaks in spring and 3 in the autumn) depending on the combination of host species and year. Interestingly, there was no apparent difference in abundance among the 3 age classes in $C$. glareolus across all 3 years. The age contribution to the 4 -way statistical interaction arose from the declining abundance of infection with increasing age in A. flavicollis in 1998, and the increasing abundance with age among M. arvalis in 1997.

\section{Associations between parasites based on categorical data}

We tested first for interactions between parasites at the level of co-occurrence/exclusion by maximum likelihood analysis of prevalence data, including all 

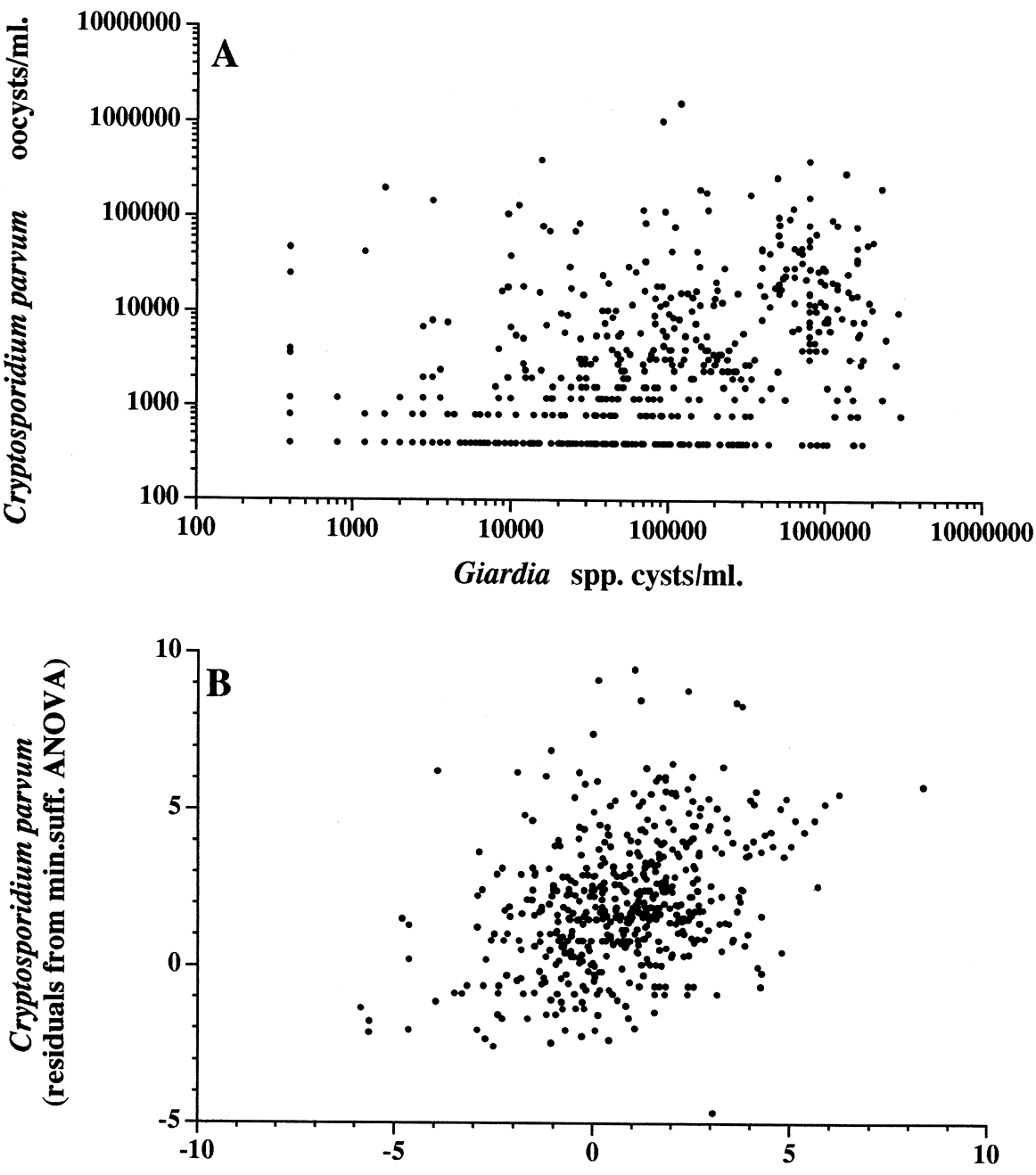

Giardia spp. (residuals from min.suff.ANOVA)

Fig. 6. Positive association between the abundance of infection of Giardia spp. and Cryptosporidium parvum. (A) Raw abundance data. (B) Residuals from minimum sufficient ANOVAs to control for the confounding effects of host species, year, season, host sex and age. See text for statistical analysis.

Table 5. Spearman Rank order correlation coefficients for the quantitative association between Cryptosporidium parvum and Giardia spp. by host species

\begin{tabular}{|c|c|c|c|c|c|c|}
\hline \multirow[b]{2}{*}{ Species } & \multicolumn{3}{|c|}{ Raw data } & \multicolumn{3}{|c|}{ Resids. from min suff. model* } \\
\hline & $r_{s} \uparrow$ & $n \ddagger$ & $P \S$ & $r_{s} \dagger$ & $n \ddagger$ & $P \S$ \\
\hline Clethrionomys glareolus & $0 \cdot 506$ & 305 & $<0 \cdot 0001$ & $0 \cdot 259$ & 305 & $<0 \cdot 0001$ \\
\hline Apodemus flavicollis & $0 \cdot 164$ & 33 & N.S. & $-0 \cdot 011$ & 33 & N.S. \\
\hline Microtus arvalis & $0 \cdot 408$ & 191 & $<0 \cdot 0001$ & $0 \cdot 348$ & 191 & $<0.0001$ \\
\hline
\end{tabular}

* Residuals from minimum sufficient 5-way ANOVAs for all host species combined derived from the analyses given in legends to Figs 3 and 4.

$\dagger$ Spearman Rank order correlation coefficient.

† Sample size, based on animals which carried both species.

$\S$ Probability for acceptance of the null hypothesis.

intrinsic and extrinsic factors recorded in the study. Three interactions incorporated both species of parasites but each interaction was confounded by the influence of 2 additional factors. It is quite clear that across most of the combinations illustrated in Fig. 5 (excepting only the spring A. flavicollis (Fig. 5C) and male $M$. arvalis Fig. (5A)) prevalence of $C$. parvum was higher among mice that also harboured Giardia spp. Positive co-occurrence of the 2 species was particularly marked in male $C$. glareolus and female

\section{CAMBridge JDURNALS}


M. arvalis (Fig. 5A), when species and age classes were combined among both sexes right across all 3 seasons (Fig. 5B), and in C. glareolus in the spring and summer (Fig. 5C).

\section{Interactions between species based on quantitative data}

Quantitative associations were tested only in mice carrying both species of parasites. We first analysed the raw data for each species and this gave a highly significant positive correlation (Fig. 6A; $r_{s}=0.465$, $n=529, P<0 \cdot 001)$. However, to control for the possibility that the relationship may have arisen through aggregations of particularly heavily infected animals among some of the subsets of data, we also tested the correlation between the residuals of minimum sufficient models derived from 5-way ANOVAs, as described earlier. This analysis gave $r_{s}=0.365,(n=529, P<0.0001$ and Fig. 6B), supporting the idea of a positive correlation between the intensity of infection of C. parvum with Giardia spp.

Finally we broke down the analysis by host species (Table 5) and this showed that the correlations were highly significant in both vole species irrespective of whether the analyses were carried out on the raw data or on residuals, but not in A. flavicollis.

\section{DISCUSSION}

The results reported in this paper firmly establish that the common woodland and grassland wild rodents in N.E. Poland constitute significant and major reservoirs of infection with Giardia spp. and C. parvum throughout 3 seasons of the year. Giardia spp. were clearly very common parasites with prevalence between 48 and $96 \%$ among the 3 rodent species examined. The overall prevalence of $C$. parvum infections was generally lower, $28-73 \%$, but nevertheless sufficient for these animals also to constitute an important natural reservoir.

Whilst high overall in both species, prevalence of infection varied significantly in relation to the factors that we included in our analyses. Perhaps the most important of these was the species of host. Both voles (C. glareolus and $M$. arvalis) showed high prevalence and intensity, but each parameter of infection for both species of parasites was considerably lower (abundance was typically 1-2 orders of magnitude lower) in A. flavicollis. The low prevalence of $C$. parvum infection in the yellow-necked mouse population $(28 \%)$ is similar to values reported elsewhere for Muridae: it was comparable with our preliminary results $(27 \%$ in Bajer, Bednarska \& Sinski, 1997; Sinski et al. 1998) and with prevalence in wood mice A. sylvaticus, in the UK (21 and $22 \%$, Chalmers et al. 1995, 1997 a, respectively) and in Spain (35\%, Torres et al. 2000). Thus mice seem to be least important as reservoir hosts for this protozoan. The discrepancy in susceptibility/resistance to infection is likely to have an intrinsic (e.g. genetic) rather than an extrinsic basis because both mice and bank voles inhabit the same forest habitats, rely on similar food resources and live in close proximity under the same climatic conditions. The much higher prevalence $(70.6 \%)$ and abundance of $C$. parvum in $C$. glareolus appears typical of this region but differs markedly from studies elsewhere (UK 8.9, 13 and 7.9\% (Chalmers et al. 1995, 1997 a; Bull et al. 1998) and Spain $20 \%$ (Torres et al. 2000)). Similarly prevalence in common voles $(73 \%)$, whilst comparable with earlier studies in the region $(68 \%$, Bajer et al. 1997; Sinski et al. 1998), differed markedly from values reported in Finland for other Microtidae $(0.8 \% \quad M$. agrestis, $2.4 \%$ C. glareolus, $0 \% M$. оесопоти; Laakkonen, Soveri \& Henttonen, 1994).

Throughout the world rodents commonly serve as reservoirs of infection for Giardia spp., although prevalence varies by region and species (Chilvers et al. 1998). Prevalence can be very high, as in our study and elsewhere (e.g. $100 \%$ of $M$. richardsoni and $M$. longicaudus in the USA, Pacha et al. 1987; $75 \%$ of muskrats in Germany, Karanis et al. 1996b). We detected the highest prevalence $(96.3 \%)$ in $M$. arvalis from post-agricultural habitats comprising abandoned fields and previously extensively grazed meadows. Prevalence in bank voles was only marginally lower $(94 \%)$ but these hosts were exclusively sampled from the woodland areas in our study sites. In addition to our earlier paper (Bajer, Bednarska $\&$ Sinski, 1998), only 1 other study has reported on the prevalence of Giardia spp. in small woodland rodents from Europe (C. glareolus, A. flavicollis and A. sylvaticus), but the data are pooled and an overall prevalence of $>50 \%$ is reported (Karanis et al. 1996a).

The second significant factor influencing prevalence and abundance of infection was temporal. Quite clearly, there were significant changes between the years, in the case of $C$. parvum, with maximum prevalence and abundance in 1998. This temporal variation in $C$. parvum in Poland contrasts with the relative stability of prevalence in C. glareolus, $A$. sylvaticus and Rattus norvegicus in the UK (Chalmers et al. $1997 a$; Quy et al. 1999). However, betweenyear differences in prevalence have been observed among Mus musculus $(12.4 \%$ in $1992,22.5 \%$ in 1993 , and $50 \%$ in the spring 1994; Chalmers et al. $1997 a$ ) and C. glareolus (16.3\% in 1994 and 1.5\% 1995; Bull et al. 1998) but with prevalence markedly lower than our values. Although we detected a between-year difference in the prevalence of Giardia spp., the overall prevalence with these species was so high that the annual fluctuations were minor in comparison. Interestingly, maximum prevalence and abundance was detected in 1998, as with C. parvum.

The third source of variation in prevalence and abundance arose from seasonal effects. For $C$. 
parvum, our data indicate that peaks are more likely to occur in the spring and summer, rather than the autumn, but there was no convincing strong pattern across the seasons during the 3 years of the study. These findings generally concur with earlier reports (Torres et al. 2000; Quy et al. 1999) which have reported contrasting seasonal changes in prevalence among different rodent species, inhabiting various ecosystems. A seasonally low prevalence in the autumn was observed among rats on livestock farms in the UK, but no obvious peak in other seasons, whilst on arable farms prevalence dropped markedly in the winter (Quy et al. 1999). Similarly low prevalence was observed in the winter among three species of rodents, followed by higher prevalence in the summer and an autumnal peak (Chalmers et al. $1997 a$ ), coinciding with calving periods on local farms. However, there were no active farms in the vicinity of our study sites and the seasonal changes therefore reflect fluctuations in transmission among the wild animal reservoir. The seasonal effect was not as marked for Giardia spp., although fluctuations were more evident in A. flavicollis, in which prevalence rose from summer to autumn. The only comparable data are from a Giardia spp. survey in a wide range of hosts from New Zealand (Chilvers et al. 1998), where no seasonal differences in prevalence were found among house mice and ship rats.

Interestingly, intrinsic factors played a lesser role in determining prevalence and abundance of infection. Firstly, the prevalence of $C$. parvum did not vary between the sexes in all 3 host species in our study, in line with some earlier reports (Chalmers et al. 1997 a ; Bull et al. 1998) but contrasting with Quy et al. (1999; prevalence higher among male rats) and Torres et al. (2000; prevalence higher among female A. sylvaticus and C. glareolus).

Secondly, there was a significant age effect and some indication that it arose principally through generally lower prevalence and abundance of $C$. parvum among the oldest animals in our study. This declining prevalence with increasing age might indicate some development of immunity to reinfection among the older animals, which would have had a greater opportunity to be exposed to infection. Nevertheless, even among these animals overall prevalence was high, so at best, this might relate only to a relatively small subset of the population. Young animals are expected to disperse from their parents' territory (intrapopulation migrants) and therefore are likely to be important in spreading the parasite to new locations. Much the same conclusion emerged from the studies of Quy et al. (1999), in which overall prevalence was lower than in our study $(24 \%)$ but varied significantly in relation to age with $40 \%$ of juvenile rats carrying infection in contrast to just $12 \%$ of adults. Similarly, a higher prevalence was observed in juveniles by Torres et al. (2000) but only in C. glareolus, and not in A. sylva- ticus. Other field studies have not detected an age effect in rodents (Bull et al. 1998; Chalmers et al. $1997 a$ ), and since the average life-expectancy of voles in the wild is just 1.5-3.0 months (Pucek, Ryszkowski \& Zejda, 1969/1970) and C. parvum does not pose a life-threatening infection, it is possible that there is little selection pressure for the evolution of strong protective responses. For the longer-lived species such as yellow-necked mice (mean life length in wild $=2 \cdot 9-3 \cdot 6$ months and under laboratory conditions 4-5 years; Bobek, 1969) resistance to $C$. parvum may bring fitness benefits and in our study both prevalence and abundance were low in the oldest class of these rodents.

Under laboratory conditions male mice experience more severe and longer lasting infections with Giardia spp. than females (Daniels \& Belosevic, 1995) but in accordance with other field studies (Marino et al. 1992; Chilvers et al. 1998) neither prevalence nor abundance of Giardia spp. were affected by host sex or age in our study. Although we do not present data here, we also examined recaptured animals and among these, $C$. parvum infections were often persistent, some animals among both sexes continuing to excrete oocysts for more than 3-6 months.

The two intestinal protozoa showed significant cooccurrence and in animals carrying both species there was a strong positive correlation between the abundance of infection with each, especially in voles. The trophozoites of these two species occupy different microhabitats in the intestine: $C$. parvum trophozoites are intracellular and freely mobile Giardia spp. trophozoites are loosely attached to villi. The presence of one might facilitate infection with the second species or both species may be focused in susceptible animals with weakened resistance or those showing behavioural patterns predisposing to infection. During the survey on Skomer bank voles (Bull et al. 1998) the majority of $C$. parvum infections were detected in voles coinfected with $C$. muris. These species also occupy different habitats (intestine and stomach, respectively) and thus their co-occurrence is very possible.

Finally, this study constitutes the first comprehensive report and analysis of the prevalence and abundance of infection with 2 medically important intestinal protozoa, C. parvum and Giardia spp., in 3 rodent species from N.E. Europe. To our knowledge, apart from species identification in different hosts including humans, rodents and livestock (Bednarska, Bajer \& Sinski, 1988; Sinski et al. 1998; Majewska et al. $1999 a, b)$, no other studies from this region of Europe have probed as deeply the factors that influence both prevalence and abundance of these opportunistic protozoan parasites. Our data establish firmly that at least 2 species of voles inhabiting 2 quite different habitats maintain these pathogens in the natural environment throughout the years and 
seasons. Thus they may act as zoonotic reservoir of C. parvum and Giardia spp. for transmission to other animals including humans, although whether rodent genotypes, and specifically those parasitizing voles in our study sites, are infective to humans and livestock, remains to be established.

We are grateful to the British Council, UK and the State Committee for Scientific Research (KBN), Poland for financial support for this study (KBN grants 6PO4C02318, 6PO4C09721, KBN-BC grants no 855 and 930.

\section{REFERENCES}

ABD EL-WAHED, M. M., SALEM, G. H. \& EL-ASSALy, T. M. (1999). The role of wild rats as a reservoir of some internal parasites in Qalyobia governorate. Fournal of the Egyptian Society of Parasitology 29, 495-503.

ADAMCZEWSKa-ANDRZEJEWska, K. D. (1973). The lens weight as indicator of age in the wild Microtus arvalis population. Bulletin de l'Academie Polonaise des Sciences Cl. II. 21, 331-336.

BAJER, A., BEDNARSKa, M. \& SINSKi, E. (1997). Wildlife rodents form different habitats as a reservoir for Cryptosporidium parvum. Acta Parasitologica 42, 192-194.

BAJER, A., BEDNARSKa, M. \& SINSKi, E. (1998). Gryzonie róznych siedlisk jako rezerwuar Giardia sp. w Polsce. Biuletyn Metodyczno-Organizacyjny Instytutu Medycyny Morskiej i Tropikalnej 31, 125.

BAJER, A., PAWEŁCZYK, A., BeHNKe, J. M., GILBERT, F. S. \& SINSKI, E. (2001). Factors affecting the component community structure of haemoparasites in bank voles (Clethrionomys glareolus) from the Mazury Lake District region of Poland. Parasitology 122, 43-54.

BEDNARSKa, M., BAJER, A. \& SINSKI, E. (1998). Calves as a potential reservoir of Cryptosporidium parvum and Giardia sp. Annals of Agriculture and Environmental Medicine 5, 135-138.

BEHNKE, J. M., LEWIS, J. W., MOHD ZAIN, S. N. \& GILbERT, F. s. (1999). Helminth infections in Apodemus sylvaticus in southern England: interactive effects of host-age, sex and year on prevalence and abundance of infections. Fournal of Helminthology 73, 31-44.

вовек, в. (1969). Survival, turnover and production of small rodents in a beech forest. Acta Theriologica 14, 191-210.

Bull, S. A., Chalmers, R. M., SturdeE, A. P. \& Healing, T. D. (1998). A survey of Cryptosporidium species in Skomer bank voles (Clethrionomys glareolus skomerensis). Fournal of Zoology, London 244, 119-122.

Chalmers, R. M., STURdeE, A. P., Bull, S. A. \& Miller, A. (1995). Rodent reservoirs of Cryptosporidium. In Protozoan Parasites and Water (ed. Betts, W., Casemore, D., Fricker, C., Smith, H. \& Watkins, J.), pp. 63-66. Royal Society of Chemistry Special Publication, Cambridge.

Chalmers, R. M., SturdeE, A. P., BUll, S. A., Miller, A. \& WRIGHT, s. E. (1997a). The prevalence of Cryptosporidium parvum and C. muris in Mus domesticus, Apodemus sylvaticus and Clethrionomys glareolus in an agricultural system. Parasitology Research 83, 478-482.
CHALMERS, R. M., STURDEE, A. P., MELlORS, P., NICHOLSON, V., LAWLOR, F., KENNY, F. \& TIMPSON, P. (1997b). Cryptosporidium parvum in environmental samples in the Sligo area, Republic of Ireland: a preliminary report. Letters in Applied Microbiology 25, 380-384.

Chilvers, B. L., COWAN, P. E., Waddington, D. C., Kelly, P. J. \& BROWN, T. J. (1998). The prevalence of infection of Giardia spp. and Cryptosporidium spp. in wild animals on farmland, south-eastern North Island, New Zealand. International Fournal of Environmental Health Research 8, 59-64.

Cicirello, H. G., KeHL, K. S., ADDiss, D. G., ChUsid, M. J., GLASS, R. I., DAVIS, J. P. \& HAVENS, P. L. (1997).

Cryptosporidiosis in children during a massive waterborne outbreak in Milwaukee, Wisconsin: clinical, laboratory and epidemiologic findings. Epidemiology and Infection 119, 53-60.

CRAWLEY, M. T. (1993). GLIM for Ecologists. Blackwell Scientific Press, Oxford.

DANiels, C. W. \& Belosevic, M. (1995). Comparison of the course of infection with Giardia muris in male and female mice. International Fournal for Parasitology 25, 131-135.

DASH, K. M., HALL, E. \& BARgER, I. A. (1988). The role of arithmetic and geometric mean worm egg counts in faecal egg count reduction tests and in monitoring strategic drenching programs in sheep. Australian Veterinary fournal 65, 66-68.

ELliott, J. M. (1977). Some Methods for the Statistical Analysis of Samples of Benthic Invertebrates.

Freshwater Biological Association, Cumbria, UK.

FUllagar, P. J. \& JEWEll, P. A. (1965). Marking small rodents and the difficulties of using leg rings. Fournal of Zoology, London 147, 224-228.

GarCIA, L. S. \& BRUCKNeR, D. A. (1988). Diagnostic Medical Parasitology. Elsevier Science Publishing, London.

DE GRAaF, D. C., VANOpdenbosch, E., ORTEGa-Mora, L. M., AbBASSI, H. \& PEETERS, J. E. (1999). A review of the importance of cryptosporidiosis in farm animals. International Fournal for Parasitology 29, 1269-1287.

GRIFFITHS, J. K. (1998). Human cryptosporidiosis: epidemiology, transmission, clinical disease, treatment, and diagnosis. Advances in Parasitology 40, $37-86$.

HenRicksen, s. \& POHLENZ, J. (1981). Staining of cyptosporidia by modified Ziehl-Neelsen technique. Acta Veterinary Scandinavian 22, 594-596.

Karanis, P., OPIELA, K., AL-ARousi, M. \& SEITZ, H. M. (1996a). A comparison of phase contrast microscopy and an immunofluorescene test for the detection of Giardia spp. in faecal specimens from cattle and wild rodents. Transactions of the Royal Society of Tropical Medicine and Hygiene 90, 250-251.

KARANis, P., OPIEla, K., RENOTH, s. \& SEITZ, H. M. (1996b). Possible contamination of surface waters with Giardia spp. through muskrats. Zentralblatt für Bakteriologie 284, 302-306.

Kozakiewicz, M. (1976). The weight of eye lens as the proposed age indicator of the bank vole. Acta Theriologica 21, 314-316.

LAAKKonen, J., SOveri, T. \& HentTonen, H. (1994). Prevalence of Cryptosporidium sp. in peak density 
Microtus agrestis, Microtus oeconomus and Clethrionomys glareolus populations. Fournal of Wildlife Diseases 30, 110-111.

MajEWSKa, A. C. \& KASPRZAK, W. (1995). Wodnopochodne epidemie Giardia. Wiadomości Parazytologiczne 41, 25-31.

MAJEWSKa, A. C., KASPRZAK, W., WERNER, A. \& KOZAKIEWICZ, B. (1999b). Investigation on cryptosporidiosis in humans and livestock from the same localities. Acta Parasitologica 44, 211-214.

MajeWska, A. C., WERner, A., SUlima, P. \& LUTy, T. (1999a). Survey on equine cryptosporidiosis in Poland and the possibility of zoonotic transmission. Annals of Agricultural and Environmental Medicine 6, 161-165.

MARGOLIS, L., ESCH, G. W., HOLMES, J. C., KURIS, A. M. \& SCHAD, G. A. (1982). The use of ecological terms in parasitology (report of an ad hoc committee of The American Society of Parasitologists). Fournal of Parasitology 68, 131-133.

MARINO, M. R., BROWN, T. J., WADDINGTON, D. C., BROCKIE, R. E. \& KELLY, P. J. (1992). Giardia intestinalis in North Island possums, house mice and ship rats. New Zealand Veterinary Fournal 40, 24-27.

MAZURKiewicZ, M. (1972). Density and weight structure of populations of the bank vole in open and enclosed area. Acta Theriologica 17, 455-465.

MORRIS, P. (1972). A review of mammalian age determination methods. Mammal Review 2, 69-104.

NOVOTNY, T. E., HOPKINS, R. S., SHILlaM, P. \& JANOFF, E. N. (1990). Prevalence of Giardia lamblia and risk factors for infection among children attending daycare facilities in Denver. Public Health Report 105, $72-75$.

o'donoghue, P. J. (1995). Cryptosporidium and cryptosporidiosis in man and animals. International Fournal for Parasitology 25, 139-195.

OKHUYSEN, P. C., ChAPpell, C. L., CRABB, J. H., STERLING, C. R. \& DUPONT, H. L. (1999). Virulence of three distinct Cryptosporidium parvum isolates for healthy adults. Fournal of Infectious Diseases 180, 1275-1281.

PACHA, R. E., Clark, G. W., Williams, E. A., CARTER, A. M., SChefFelmaier, J. J. \& Debusschere, P. (1987). Small rodents and other mammals associated with mountain meadows as reservoir of Giardia spp. and Campylobacter spp. Applied and Environmental Microbiology 53, 1574-1579.

PIENIAZEK, N. J., BORNAY-LLINARES, F. J., SLEMENDA, S. B., DA SILVA, A. J., MOURA, I. N. S., ARROWOOD, M. J., DitRich, O. \& ADDISS, D. G. (1999). New Cryptosporidium genotypes in HIV-infected persons. Emerging Infectious Diseases 5, 1-6.
Poulin, R. (1993). The disparity between observed and uniform distributions: a new look at parasite aggregation. International Fournal for Parasitology 23, 937-944.

PUCEK, Z., RYSZKOWSKI, L. \& ZEJDA, J. (19691970). Estimation of average length of life in bank vole Clethrionomys glareolus (Schreber, 1780). In Energy Flow Through Small Mammal Populations (ed. Petrusewicz, K. \& Ryszkowski, L.), pp. 187-201. PWN, Warszawa.

QUY, R. J., COWAN, D. P., HaYNes, P. J., STURdeE, A. P., CHALMERS, R. M., BODLEY-TiCKELl, A. T. \& BULL, S. A. (1999). The Norway rat as a reservoir host of Cryptosporidium parvum. Fournal of Wildlife Diseases 35, 660-670.

Sinski, E., BEDNARSKa, M. \& BAJER, A. (1998). The role of wild rodents in ecology of cryptosporidiosis in Poland. Folia Parasitologica 45, 173-174.

SINSKi, E., HLEBOWICZ, E. \& BEDNARSKa, M. (1993). Occurrence of Cryptosporidium parvum infection in wild small mammals in District of Mazury Lake (Poland). Acta Parasitologica 38, 59-61.

STURdeE, A. P., Chalmers, R. M. \& BUll, S. A. (1999). Detection of Cryptosporidium oocysts in wild mammals of mainland Britain. Veterinary Parasitology 80, 273-280.

ŚWIERCZEWSKa, A. A. (1981). Tempo wzrostu i morfologiczne kryteria wieku myszy wielkookiej lesnej. M.Sc. thesis, Department of Ecology, University of Warszawa.

TONKS, M. C., BROWN, T. J. \& IONAS, G. (1991). Giardia infection of cats and dogs in New Zealand. New Zealand Veterinary Fournal 39, 33-34.

TORRES, J., GRaCENEA, M., GOMEZ, M. S., ARrizabalaGa, A. \& GONZALES-MoReno, o. (2000). The occurrence of Cryptosporidium parvum and C. muris in wild rodents and insectivores in Spain. Veterinary Parasitology 92, 253-260.

WALLIS, P. M., ERLANDSEN, S. L., ISAAK-RENTON, J. L., OLSON, M. E., ROBERTON, W. J. \& VAN KEULEN, H. (1996). Prevalence of Giardia cysts and Cryptosporidium oocysts and characterization of Giardia spp. Isolated from drinking water in Canada. Applied and Environmental Microbiology 62, 2789-2797.

Webster, J. P. \& MacDONALD, D. W. (1995).

Cryptosporidiosis reservoir in wild brown rats (Rattus norvegicus) in the UK. Epidemiology and Infection 115, 207-209.

WILSON, K. \& GRENFELL, B. T. (1997). Generalized linear modelling for parasitologists. Parasitology Today 13, 33-38. 